\title{
Another color morph of Sporophila Seedeater from the capuchinos group (Aves, Emberizidae)
}

\author{
Márcio Repenning, Cristiano E. Rovedder \& Carla S. Fontana
}

Laboratório de Ornitologia, Museu de Ciências e Tecnologia, Curso de Pós-Graduação em Zoologia, Pontifícia Universidade Católica do Rio Grande do Sul, Av. Ipiranga, 6681, 90.619-900 Porto Alegre, RS. (carla@pucrs.br)

\begin{abstract}
The genus Sporophila (Cabanis, 1844) unites about 30 species of small seedeaters that predominantly inhabit open or semi-open areas in the Neotropical region. The taxonomy of this group is based on morphological studies from collected male specimens. The dynamic spatial and temporal variation in the male plumage and lack of knowledge of their vocalizations make it difficult to properly diagnose some species even today, so these two aspects account for the existing taxonomic dilemmas involving Sporophila. During a four-year field study, we investigated the natural history of a breeding population of Sporophila melanogaster (Pelzeln, 1870). This is an endemic species in Brazil, which reproduces in the high-altitude grasslands of the Atlantic Forest biome. We found four male specimens with clearly diagnosable plumage, distinct from the typical form of the species. Here we describe this previously unreported plumage form. Based on the evaluation of habitat use, vocalization, and reproductive behavior, we tested two hypotheses regarding its taxonomic status. We concluded that this is another case of an intra-specific color morph within the seedeaters of the "capuchinos" group.
\end{abstract}

KEYWORDS. Sporophila melanogaster, Black-bellied seedeater, vocal repertory, habitat use, natural history.

RESUMO. Outro morfo de Sporophila do grupo dos caboclinhos (Aves, Emberizidae). O gênero Sporophila (Cabanis, 1844) reúne cerca de 30 espécies de papa-capins de pequeno porte, que habitam predominantemente áreas abertas ou semi-abertas na região Neotropical. A taxonomia do gênero é baseada em estudos morfológicos de exemplares machos adultos coletados. A variação espaçotemporal dinâmica na coloração da plumagem dos machos e a falta de conhecimento sobre suas vocalizações torna difícil diagnosticar adequadamente algumas espécies, de modo que esses dois aspectos são responsáveis pelos dilemas taxonômicos envolvendo Sporophila. Durante quatro anos estudamos a história natural da população reprodutiva de Sporophila melanogaster (Pelzeln, 1870). Essa é uma espécie endêmica do Brasil, que reproduz em campos de altitude do bioma Mata Atlântica. Ao longo desse estudo foram encontrados quatro exemplares machos com plumagem claramente distinta da forma típica conhecida para a espécie. Aqui nós descrevemos essa nova forma, com base na avaliação do uso do hábitat, vocalização e comportamento reprodutivo, e testamos duas hipóteses em relação a sua situação taxonômica. Concluimos tratar-se de mais um morfo de coloração em Sporophila do grupo dos caboclinhos.

PALAVRAS-CHAVE. Sporophila melanogaster, caboclinho-de-barriga-preta, repertório vocal, hábitat, história natural.

The genus Sporophila (Cabanis, 1844) unites about 30 small-sized passerine species, mainly seed-eaters that usually inhabit open or semi-open areas in the Neotropical region (MEYER DE SCHAUENSEe, 1952; RidGely $\&$ TUDOR, 1989). The plumage pattern and the color saturation in this genus show wide intra- and inter-specific variations (HellmaYr, 1938; Ouellet, 1992; Sick, 1997), which somewhat weaken classifications that are based only on plumage characteristics of adult males (HELLMAYR, 1938; Meyer de Schauensee, 1952; Stiles, 2004).

According to Ouellet (1992) and Stiles (1996), it is necessary to gather new information on the ecology, behavior, and molecular data in order to determine the species limits within Sporophila and the similarities among them. Studies on voice and behavior, for example, although still insufficiently used for this group, have been contributing effectively to solving taxonomic difficulties in the genus (SChwartz, 1975; ARETA, 2008; ARETA et al., 2011). On the other hand, molecular approaches have revealed shallow genetic divergence among several species, as is the case for the ten species that form the "Southern Capuchinos group" (LiJTMAER et al., 2004; Campagna et al., 2009).

Important advances in the general understanding of the capuchinos have been gained, especially in the identification of new color morphs to several species, as well as of this group's natural history (ARETA, 2008, 2009; FACCHINETTI et al., 2008; LIMA, 2008; ARETA et al., 2011). Sporophila zelichi (Narosky, 1977), for example, was proposed as a color morph of Sporophila palustris (Barrows, 1883), which invalidates the species status of the former (ARETA, 2008). Likewise, "caraguata" was suggested to be a color morph for Sporophila ruficollis (Cabanis, 1851), and a color morph is presently being described for Sporophila hypoxantha Cabanis, 1851 (Juan I. Areta, pers. comm., and M.R., pers. obs.). The descriptions of these new forms have been based mainly on studies of vocalization and habitat preference (ARETA, 2008; ARETA et al., 2011).

In the course of extensive fieldwork in extreme southern Brazil, we found some completely black with gray crown individuals of capuchinos. We hypothesized that this morphotype could be a phenotype related to the Black-bellied Seedeater (Sporophila melanogaster). Aiming to provide useful new information for diagnosis of South American capuchinos, we describe herein this new, identifiable plumage type and discuss its taxonomic status based on habitat use characteristics, voice and behavior. In view of recent studies that proposed color morphs for capuchinos (ARETA, 2008; ARETA et al., 2011), we evaluated whether the specimens found are (1) individuals of Sporophila melanogaster with intra- 
specific variation in their plumage (color morph); or (2) a new species, sympatric with $S$. melanogaster.

Proposed hypotheses. We predicted that habitat segregation would be a strong mechanism during the process of speciation and adaptive radiation for closely related species (CoDy, 1985; BeLTMAN \& HACCOU, 2005), especially of Sporophila (SicK, 1967), and that vocalization could be an important element for mate recognition within species (Kroodsma, 1996). Therefore, the natural preference for a specific habitat and a particular voice for males and females would act as key elements for finding and recognizing reproductive partners from the same species (Specific Mate Recognition System [SMRS]), thus allowing us to determine breeding units (see ARETA, 2008). The hypotheses that we proposed were: 1) is it a color morph of S. melanogaster (Color Morph Hypothesis $[\mathrm{CMH}]$ ) or 2) could the new plumage form represent a valid species (Valid Species Hypothesis [VSH])? The first hypothesis predicted that the new form would occur in the same geographical area and would show the same habitat preferences, voice, and behavior patterns as $S$. melanogaster. The second hypothesis assumed that these individuals would have different habitat preferences (or even different spatial distribution patterns), and/or would differ in vocal repertories.

\section{MATERIAL AND METHODS}

During four consecutive breeding seasons (20062010), from October to March, we attempted to locate individuals of Sporophila in the grasslands of the southern Brazilian highlands (over $700 \mathrm{~m}$ a.s.l.) in the states of Rio Grande do Sul (RS) and Santa Catarina (SC) (Fig. 1). The total field work effort was 250 days. We collected data on habitat specificities of each Sporophila species, their vocal repertory including songs associated with color patterns of males and females, and reproductive behavior.

The preference of Sporophila melanogaster and of the new plumage form for a specific habitat was measured by the proportion of encounters in established territories in one of the following habitats: a) valley

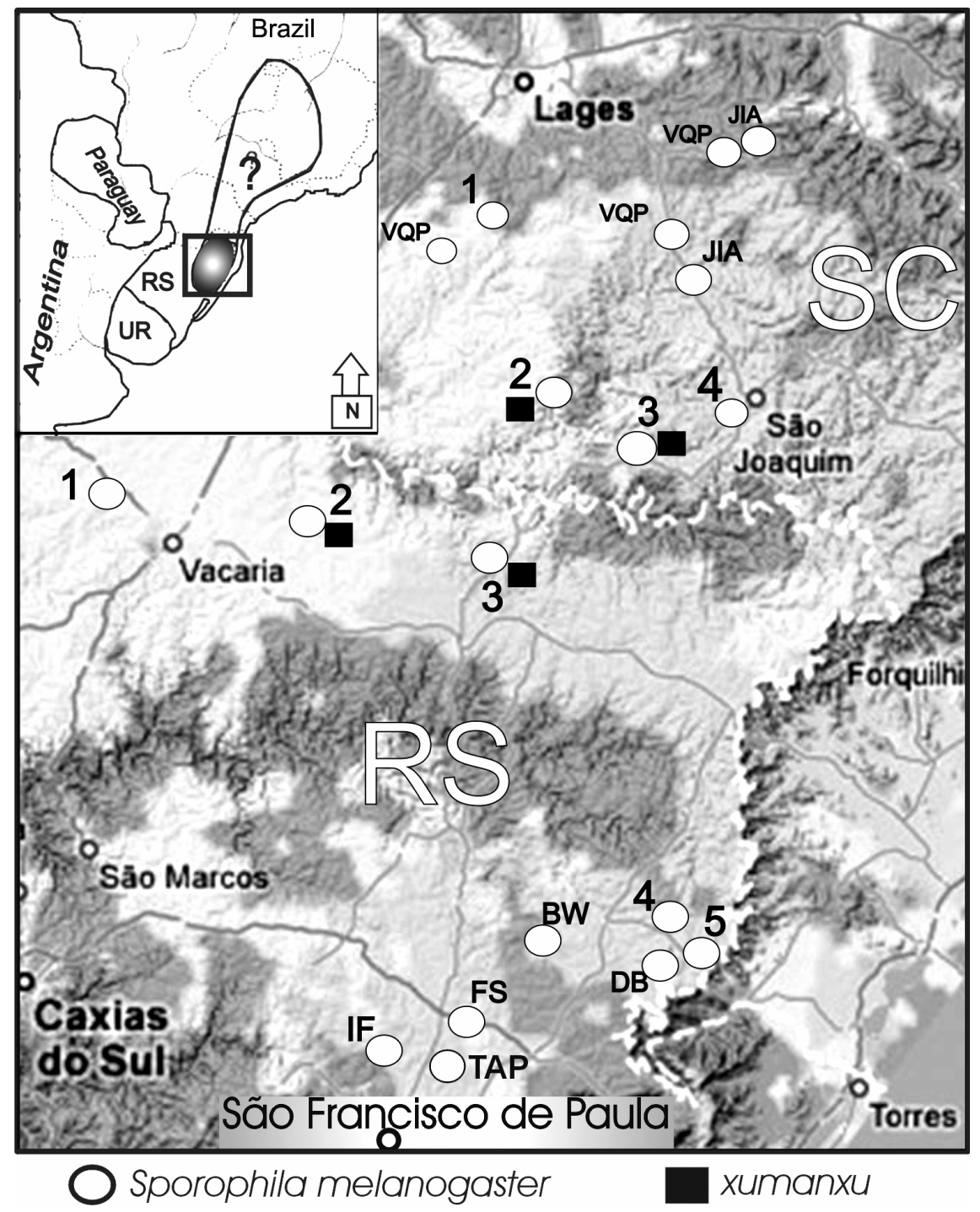

Figure 1. Locations where individuals of Sporophila melanogaster (Pelzeln, 1870) were recorded. White dots and black squares indicate recording locations of $S$. melanogaster and хитапхи, respectively (see Table I). Smaller map: elliptical black spot indicate the breeding grounds, and the symbol "?" the wintering grounds of S. melanogaster, adapted from RidGELY \& TUDOR (1989). 
shrubby grassland - dry fields with small patches of saturated ground and a few wet areas; high density of small bushes (Vernonia chamaedris, Eupatorium spp., and Baccharis spp.) mixed with tall grasses, mainly Saccharum angustifolium and Eleocharis spp., and also Eryngium horridum (Apiaceae), on drier soils, and generally found in valleys and steep terrain; b) guamirim fields: exclusively dry grass, mostly composed by tall clumps (2 to $3 \mathrm{~m}$ ) formed by "guamirim" (Myrcia bombycina) and scattered small trees (Agarista eucalyptoides, Schinus terebinthifolius), located on hilly, rocky patches (below 1,000 m a.s.1.); c) caraguatá wetlands or bogs: distinguished by the abundant presence of "caraguatá" (Eryngium pandanifolium, E. elegans), turf (Sphagnum spp.), several Cyperaceae species, and clumps of Poaceae species in the transition to drier areas. This latter vegetation type occupies undulating, saturated patches of soil without rocks, at altitudes of about $1,000 \mathrm{~m}$.

Songs were recorded with Sennheiser ME 62, 66, or 67 microphones and Sony TC-D5M and PCM D50 recorders. We also extracted audio from recordings made with a Sony DCR-VX2100 NTSC camera (Tab. I). These recordings were deposited in the audio collection of the Cornell Laboratory of Ornithology. Spectrograms were developed with the software Raven 1.2. Note types were separated and identified based on the shape, frequency, and duration of all notes emitted by each bird recorded. We compared the order of the notes (phrases) of individual males of S. melanogaster with the vocalizations of the specimens with the new plumage morph. To avoid analyzing replicates, we discarded recordings of birds for which there was no visual contact by the observer, especially in areas where more than two individuals were recorded. We experimentally submitted territorial males from both phenotypes to playbacks of each other's songs. Secondly, we compared the vocal repertories among females paired with males from both phenotypes determined with $100 \%$ confidence.

The description of the specimens with the new plumage pattern was based on field observation including live-caught individuals, as well as on photographs and videos. The new plumage form is here called xumanxu to facilitate presentation of the data. This informal name is used by local bird-keepers to differentiate this seedeater from other capuchinos. To test the specific status of the xumanxu morph, we followed the Recognition Species Concept (PAterson, 1985; HAFFER, 1997).

\section{RESULTS}

We found four xumanxu and 132 S. melanogaster breeding males. The xumanxu males had a very different color pattern from adult $S$. melanogaster males, showing coloration pattern equivalent to males of $S$. cinnamomea (Lafresnaye, 1839), except that the cinnamon/chestnut regions are replaced with black (Figs 2-7), and also similar to the $S$. bouvreuil (Statius Muller, 1776) named form.

Description of xumanxu individuals - males 1 and 3. Male 1 was recorded on November 30, 2006, in São Joaquim municipality (1,187 m a.s.1.), SC (Fig. 1). Male 3 was found in November and December 2008, in Lages municipality (940 m a.s.1.), also in SC (Fig. 1). These two males had identical coloration, and are described together: a strongly contrasting bluish-gray on the forehead and crown that starts between the eyes, forming a hood, and narrows at the back of the head, extending slightly down the neck. A few whitish-gray feathers trace a line below the eyes, as in S. cinnamomea. Auriculars, nape, chin, throat, neck side, back, breast, flanks, abdomen, rump, and lower tail coverts are uniformly black. The covert feathers' fringe is gray, forming an outline on the rump. Primary and secondary remiges are black above and paler black below. From the base to the middle region of these remiges there is a strong contrasting white patch which forms the wing speculum, especially on the outside of the wings. Tertial feathers are dark, with the outer web bordered by whitish-gray. Wing coverts are black in the middle and outlined by gray. Rectrices are blackish above and dark-gray below. Tarsus and nails are dark-brown, and upper and lower maxillas are black.

Male 2. Recorded in December 2007 and January 2008, in Bom Jesus municipality (1,005 m a.s.1.), RS (Fig. 1). It differed from individuals 1 and 3 especially in having some plumage parts with vestiges of brown or drab. Tertiary and wing coverts have a black center, surrounded by light brown or medium gray. Brown feathers are predominant on the rump and sparse on the chest. This individual had an almost complete nuptial plumage, black bill, and dark-brown tarsus (Figs 4, 5).

Male 4. Recorded in November 2008, boundary between Vacaria and Bom Jesus municipalities, RS (1,000 $\mathrm{m}$ a.s.1.). This male had an incomplete nuptial plumage, in the transition from light-brown (young or eclipse plumage) to more colorful plumage, and was mating. It had a strongly contrasting bluish-gray color on the forehead and crown, starting between the eyes and narrowing at the back of the head. A few whitish-gray feathers trace a line below the eyes, as in the individuals described above. Completely black auriculars, nape, chin, throat, and neck side. Uniform brown back, breast, flanks, abdomen, rump, and lower and upper tail coverts. Primary and secondary remiges externally dark brown, with a conspicuous wing speculum. Tertiary and wing covert feathers with a brownish-black center, contrastingly surrounded by light-brown. Beak completely black with a small pale-yellow spot on the center base of the inferior maxilla. Tarsus and nails dark-brown.

Females. The three females that were paired with males of хитапхи were indistinguishable from other females of the capuchinos group in their plumage color pattern.

All these records were obtained within the distribution area of a breeding population of $S$. melanogaster (REPENNING et al., 2010). In addition, we asked local bird-keepers whether they knew a seedeater with xumanxu characteristics, and they answered in the affirmative. We were also told that these seedeaters are very rare and are always seen with the more common caboclinho-preto (i.e., the typical S. melanogaster). To our knowledge, at least two other birds of this form were captured in the surroundings of São Joaquim, SC (Ervino, pers. comm.). Another xumanxu was photographed about $20 \mathrm{~km}$ northeast of the town of São Francisco de Paula, RS, in November 2009 (Caco Schwertner, pers. comm.). 
All individuals referred to as хитапxи were observed in the same habitats used by $S$. melanogaster. Three of the xumanxu territories were established in caraguatá wetlands and one in valley shrubby grassland habitat. Of the 132 males or couples of S. melanogaster with well-defined territories found by us, 125 (94.6\%) occupied caraguatá wetlands, and only seven (5.3\%) established territories in valley shrubby grassland.

We analyzed vocalizations of four males of xumanxu and three of their respective females, as well as of 53 males and seven females of S. melanogaster (identified with $100 \%$ confidence) (Tab. I). The vocal repertory of all individuals of $S$. melanogaster is composed of 17 distinct notes, either isolated "call types" (usually bi-syllabic), or note types that compose the song, and at least five additional short notes, which we called chirps. All notes in the repertory of хитаnхи have equivalent, identical notes in the repertory of $S$. melanogaster (Figs 8-15). We found little individual variation in the vocal repertory of all the specimens studied, and no evidence of geographical variation. However, there was clearly a chronological change from the songs of $S$. melanogaster individuals recorded about 30 years ago, which showed considerable differences in the morphology of presumably homologous notes.

The vocalizations of $S$. melanogaster and xumanxu have a varied call repertory and a rather simple song, which consists of an introduction followed by a longer sequence of notes. The introduction is the "signature" of the song. It begins with two low trills (a sequence of aggregated, short notes). The first trill is usually longer (on average 24 short notes) than the second one (on average 14 notes) and they are approximately 0.3 second apart. The sound can be transcribed as "trrrraw trraw", with the first trill lasting about 0.55 seconds and the last one about 0.27 seconds. It is common to begin the song with just one or two trills, and sometimes one or two calls precede the introductory trills, as described by BELTON (1985). A high, long and descending note follows immediately, and it seems to be divided into three parts: "twah-wah-weew" (Figs 16, 17).

The second part of the song is characterized by a rhythmic sequence of clear notes, normally alternating with a very characteristic rough chirp (Figs 16, 17). This part may have slight variations among individuals, with random addition or omission of notes and changes in the order in which they are given. When complete, this fragment has four to seven different notes, and it may be restarted several times, resulting in a more complex sequence formed by many sections, with or without repeating the introduction (Fig. 18). Practically all the notes that form this second part of the song are also used in isolation as calls, and also appear in the call repertory of females (Figs 8-18).

Table I. Song recordings of Sporophila melanogaster (Pelzeln, 1870) and xumanxu in the breeding grounds in southern Brazil. Recordings by collaborators: FS, Flavio Silva; TAP, Theodore A. Parker III; BW, Bret Whitney; JIA, Juan Ignacio Areta; DB, Dante Buzetti; VQP, Vítor de Queiroz Piacentini; IF, Ismael Franz. For older recordings (i.e., FS and TAP) we indicate the year in which they were obtained (see Fig. 1).

\begin{tabular}{|c|c|c|c|}
\hline $\begin{array}{l}\text { Song samples } \\
\text { identification }\end{array}$ & $\begin{array}{l}\text { Number of individuals } \\
\text { and sex }\end{array}$ & Locality & Coordinates \\
\hline S. melanogaster & $10^{7}$ & Railroad, border with Capão Alto and Lages, SC & $28^{\circ} 2^{\prime} \mathrm{S}, 50^{\circ} 24^{\prime} \mathrm{W}$ \\
\hline S. melanogaster & $10 \sigma^{7}, 4$ 우 & Coxilha Rica, Lages, SC & $28^{\circ} 18^{\prime} \mathrm{S}, 50^{\circ} 16^{\prime} \mathrm{W}$ \\
\hline S. melanogaster & $10^{7}$ & Estância do Meio, São Joaquim, SC & $28^{\circ} 19^{\prime} \mathrm{S}, 50^{\circ} 11^{\prime} \mathrm{W}$ \\
\hline S. melanogaster & $10^{7}$ & Chapada Bonita, São Joaquim, SC & $28^{\circ} 17^{\prime} \mathrm{S}, 49^{\circ} 57^{\prime} \mathrm{W}$ \\
\hline S. melanogaster & $10^{7}$ & Fazenda Ramada, Vacaria, RS & $28^{\circ} 27^{\prime} \mathrm{S}, 51^{\circ} 1^{\prime} \mathrm{W}$ \\
\hline S. melanogaster & $1 \sigma^{\top}, 29$ & Sanga José Luis, Rio Santana, Bom Jesus, RS & $28^{\circ} 28^{\prime} \mathrm{S}, 50^{\circ} 42^{\prime} \mathrm{W}$ \\
\hline S. melanogaster & $19 \sigma^{\top}, 19$ & Arroio Água Branca, Bom Jesus, RS & $28^{\circ} 35^{\prime} \mathrm{S}, 50^{\circ} 24^{\prime} \mathrm{W}$ \\
\hline S. melanogaster & $1 \sigma^{\pi}$ & Cachoeira dos Baggio, Bom Jesus, RS & $28^{\circ} 40^{\prime} \mathrm{S}, 50^{\circ} 28^{\prime} \mathrm{W}$ \\
\hline S. melanogaster & $10^{7}$ & $\begin{array}{c}\text { Surroundings of Parque Nacional de Aparados da Serra, } \\
\text { Cambará do Sul, RS }\end{array}$ & $29^{\circ} 8^{\prime} \mathrm{S}, 50^{\circ} 5^{\prime} \mathrm{W}$ \\
\hline S. melanogaster & $1 \sigma^{7}$ & $\begin{array}{c}\text { Surroundings of Parque Nacional de Aparados da Serra, } \\
\text { Cambará do Sul, RS }\end{array}$ & $29^{\circ} 10^{\prime} \mathrm{S}, 50^{\circ} 2^{\prime} \mathrm{W}$ \\
\hline S. melanogaster & $20^{7}$ & Banhado das Capivaras, São Francisco de Paula, RS & $29^{\circ} 23^{\prime} \mathrm{S}, 50^{\circ} 25^{\prime} \mathrm{W}$ \\
\hline S. melanogaster & $10^{\top}$ & Várzea do Cedro, São Francisco de Paula, RS [FS, 1979] & \\
\hline S. melanogaster & $10^{7}$ & São Francisco de Paula, RS [TAP, 1982] & \\
\hline S. melanogaster & $10^{\top}$ & $\begin{array}{c}\text { Banhado Grande, Parque Nacional de Aparados da Serra, } \\
\text { Cambará do Sul, RS [DB] }\end{array}$ & \\
\hline S. melanogaster & $10^{\top}$ & Passo da Ilha, São Francisco de Paula, RS [BW] & \\
\hline S. melanogaster & $10^{\top}$ & Parque Municipal da Ronda, São Francisco de Paula, RS [IF] & $29^{\circ} 26^{\prime} \mathrm{S}, 50^{\circ} 32^{\prime} \mathrm{W}$ \\
\hline S. melanogaster & $10^{7}$ & Highway SC-438, Painel, SC [VQP] & \\
\hline S. melanogaster & 10 & Road to Pedras Brancas, Painel, SC [VQP] & \\
\hline S. melanogaster & $10^{7}$ & Vigia, Coxilha Rica, Lages, SC [VQP] & \\
\hline S. melanogaster & $10^{7}$ & Road to Pedras Brancas, Painel, SC [JIA] & \\
\hline S. melanogaster & $10^{\pi}$ & $\begin{array}{l}\text { State highway SC-438, between Lages and } \\
\text { São Joaquim, SC [JIA] }\end{array}$ & \\
\hline xumanxu & $10^{\top}, 1$ 우 & Estância do Meio, São Joaquim, SC & $28^{\circ} 19^{\prime} \mathrm{S}, 50^{\circ} 1^{\prime} \mathrm{W}$ \\
\hline xumanxu & $1 \sigma^{\top}, 19$ & Coxilha Rica, Lages, SC & $28^{\circ} 18^{\prime} \mathrm{S}, 50^{\circ} 16^{\prime} \mathrm{W}$ \\
\hline xumanxu & $10^{\pi}$ & Arroio Água Branca, Bom Jesus, RS & $28^{\circ} 35^{\prime} \mathrm{S}, 50^{\circ} 24^{\prime} \mathrm{W}$ \\
\hline xumanxu & $1 \sigma^{\top}, 1$ 우 & Rio Santana, Bom Jesus, RS & $28^{\circ} 29^{\prime} \mathrm{S}, 50^{\circ} 43^{\prime} \mathrm{W}$ \\
\hline
\end{tabular}



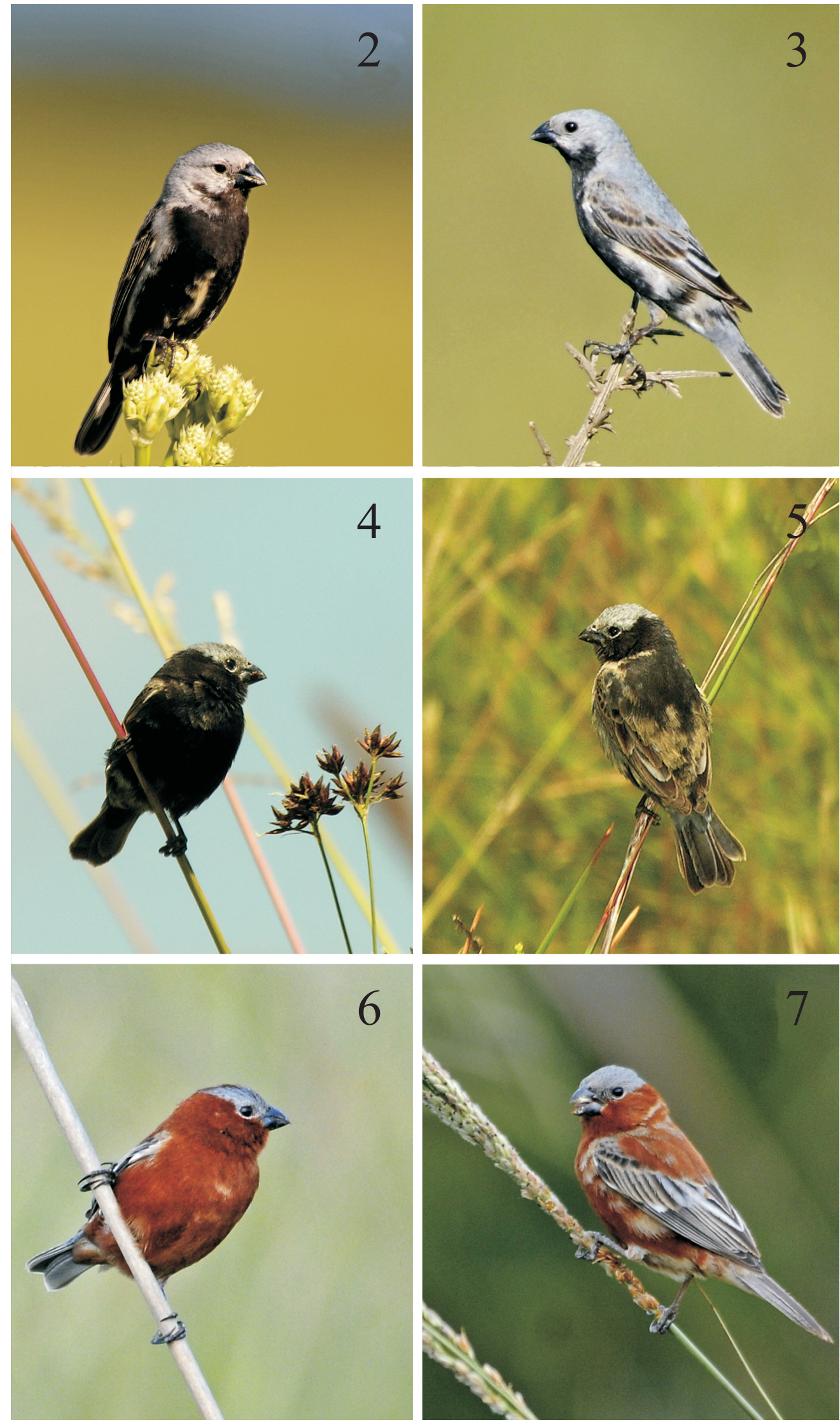

Figures 2-7. Comparative representation of plumages in Sporophila spp. capuchinos. Adult male Black-bellied Seedeater Sporophila melanogaster (Pelzeln, 1870): 2, ventral; 3, dorsal (Arroio Água Branca, Bom Jesus, Rio Grande do Sul). Adult male xumanxu: 4, ventral; 5, dorsal (Arroio Água Branca, Bom Jesus, Rio Grande do Sul). Adult male Chestnut Seedeater S. cinnamomea (Lafresnaye, 1839): 6 , ventral; 7, dorsal (Estância Leões, Dom Pedrito, Rio Grande do Sul). Photographs by M. Repenning. 
Territorial males may repeat the introduction or just a short combination of notes from the second part of the song, as if they were pieces of songs, for a long time. This usually happens in calmer situations (such as during daybreak), and during foraging when the males are hidden in the vegetation. Excited males normally emit abnormal and/or accelerated notes. These can be easily noted in recordings, when a second male sings at the same time in the background, that is, when they are disputing territories by singing.

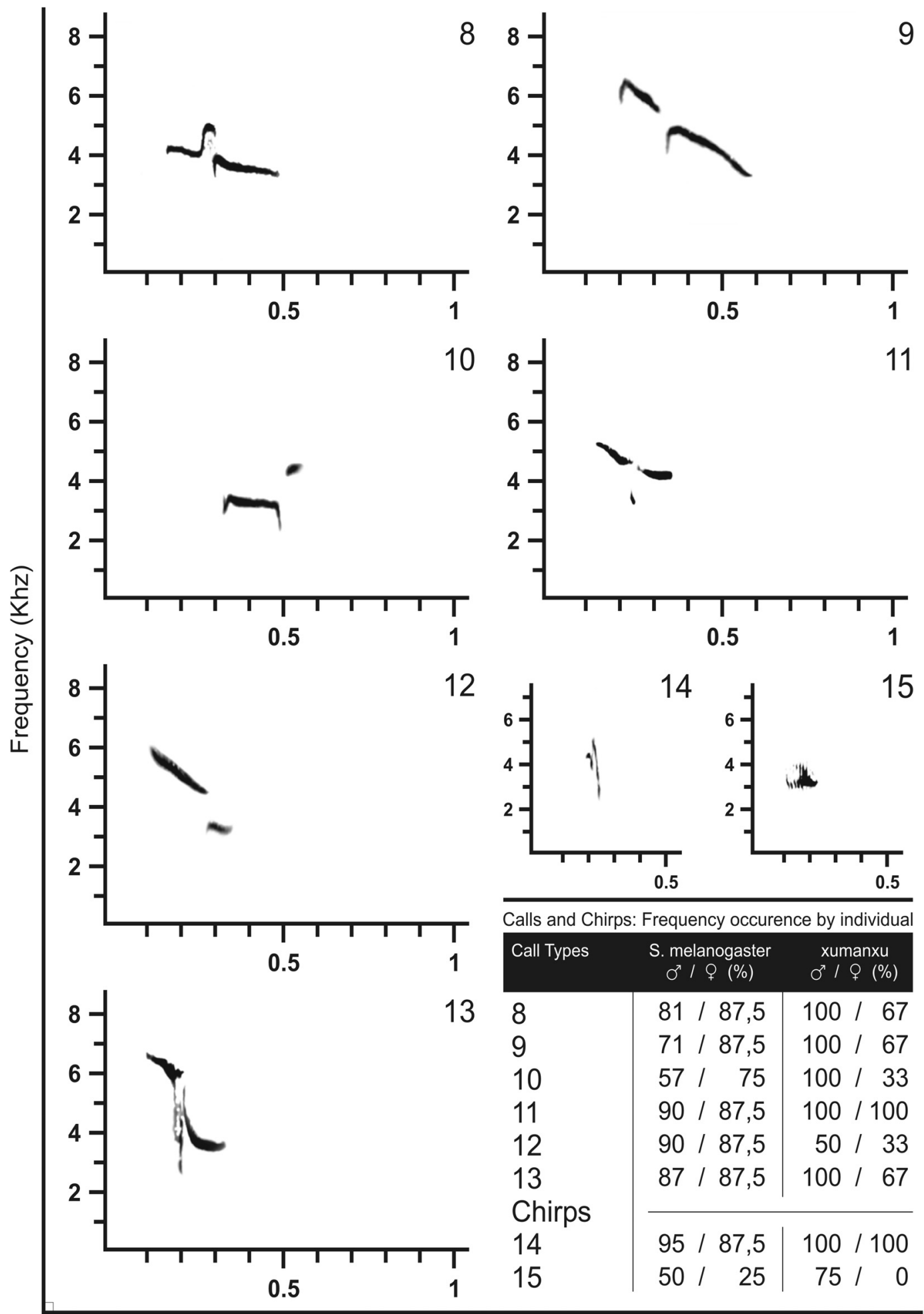

Time (s)

Figures 8-15. Spectrograms of the main calls and chirps emitted by Sporophila melanogaster (Pelzeln, 1870) $(\mathrm{n}=7$ 9 , 440 $)$ and xumanxu $\left(\mathrm{n}=39,40^{7}\right)$, with the frequency of occurrence of each note type. Figures 8 to 13 represent calls (note types), and 14 and 15 are chirps. 

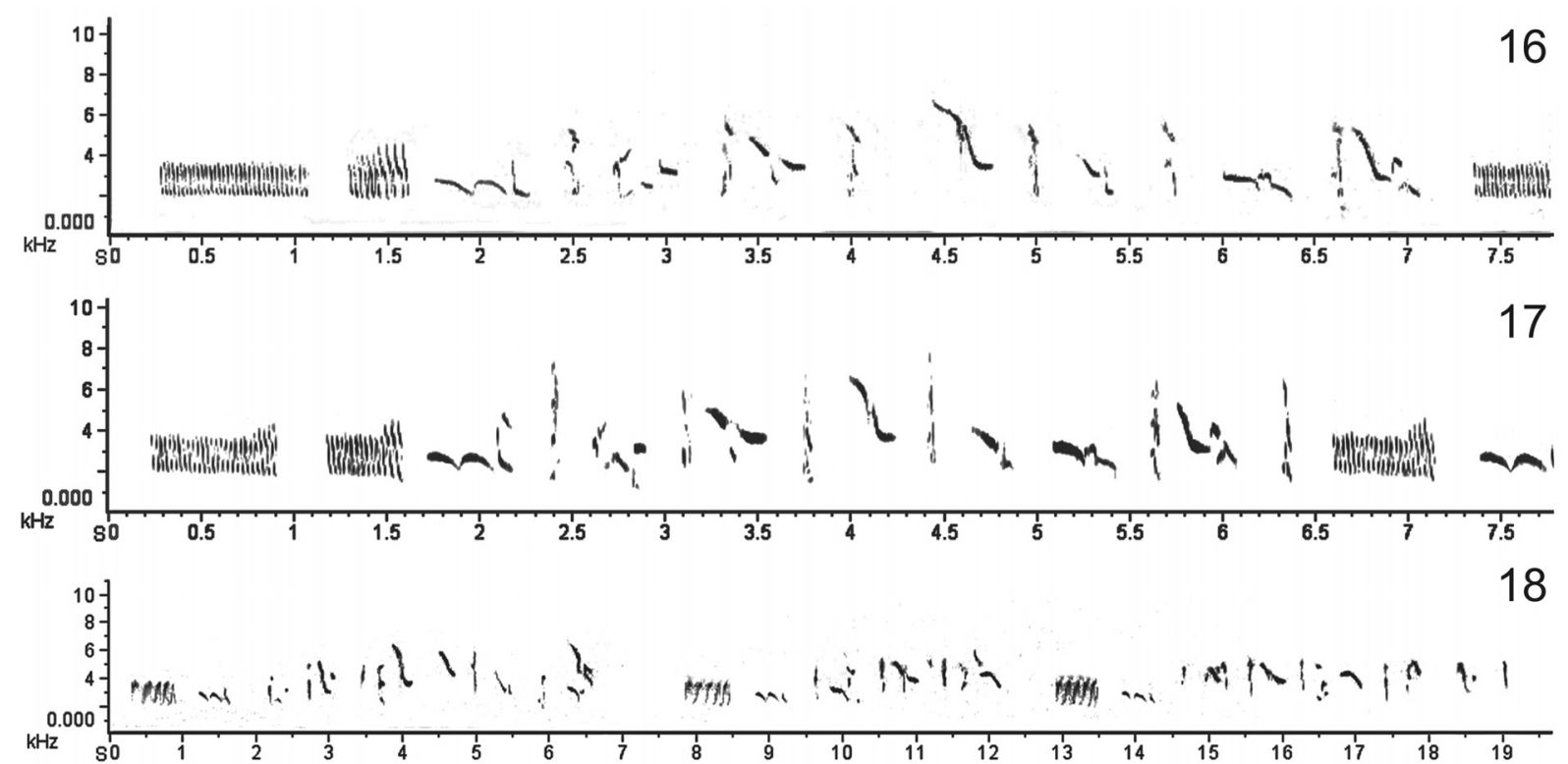

Figures 16-18. Spectrograms representing comparatively the song patterns of Sporophila melanogaster (Pelzeln, 1870) (440') and

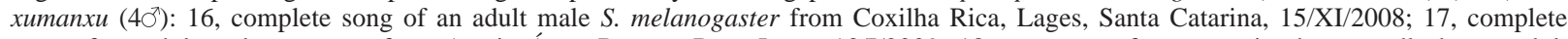
song of an adult male хumanxu from Arroio Água Branca, Bom Jesus, 13/I/2009; 18, sequence of songs emitted repeatedly by an adult male S. melanogaster from Arroio Água Branca, Bom Jesus, Rio Grande do Sul, 22/I/2007.

We determined that six calls compose the most characteristic (more frequent) repertory of $S$. melanogaster, and these calls may have slight variations in shape, all with a strongly metallic timbre (Figs 8-15). The elements of the vocal repertory of xumanxu (calls, song introduction, and complete song) were practically the same among the individuals at the four sites, including female calls. The responses to playbacks of $S$. melanogaster and хumanxu songs were reciprocal, and we interpreted them as very aggressive, typical of intraspecific interactions.

We observed several intra- and inter-specific behaviors of the four males of xumanxu. During a period of about two hours, male 1 , accompanied by a female, was observed defending its territory from a satellite $S$. melanogaster male. In all the interactions, male 1 chased away its potential competitor.

Observed for three consecutive days, male 2 apparently was not paired with a female and defended a territory between those of two typical adult $S$. melanogaster males. It attempted repeatedly to approach females, but was chased away by neighboring males. Male 2 remained singing in its territory for more than a month, and its main song perch was the inflorescence of an Eryngium pandanifolium in the wetland interior.

Male 3 was observed systematically for more than two weeks. It was paired with a female. It did not sing much, dedicating most of its time to foraging and disputing with other males, mostly those with typical $S$. melanogaster plumage. Males of Sporophila caerulescens (Vieillot, 1823) and S. hypoxantha were clearly more tolerated. Its female was also seen chasing other males of $S$. melanogaster and $S$. hypoxantha away from the nest, when she was building the nest and incubating eggs.

Male 4, also paired with a female, defended its territory in the middle of a wide wetland. It was surrounded by at least three territories belonging to males with typical $S$. melanogaster plumage. It was very aggressive towards other males, always chasing them away when its territory was invaded. Although most of its plumage was light-brown, it intimidated neighbors with full nuptial plumage.

Two xumanxu nests were monitored. They had the same shape and size as the nests of $S$. melanogaster $(\mathrm{n}=$ 64). There was a strong resemblance in the vegetation structure and composition chosen for the nest location by both phenotypic forms.

Based on results we rejected the VSH for xumanxu, and considered it as a color morph $(\mathrm{CMH})$ of $S$. melanogaster.

\section{DISCUSSION}

Historically, plumage variations in Sporophila have usually been attributed to hybridization or aberrant plumage (Sick, 1963; Short, 1969; De LAS CASAS, 2004). Based on the plumage color pattern, hybridization of $S$. cinnamomea vs. S. melanogaster would be a possible explanation for the хиmanxu phenotype. However, this hypothesis was rejected a priori since the two species have allopatric breeding sites (see BENCKE et al., 2003; REPENNING et al., 2010). Another possible hypothesis is that the xumanxu is a color morph of S. cinnamomea. This hypothesis must also be rejected, based on the allopatric distribution between $S$. cinnamomea and xumanxu. Because $S$. melanogaster and xumanxu have the same habitat preference and occur syntopically, have the same vocal repertory, and show the same behavior we considered xumanxu as a color morph $(\mathrm{CMH})$ of $S$. melanogaster.

Traditional taxonomic evaluations laid much emphasis on male plumage coloration patterns in Sporophila (TodD, 1915; HellmaYR, 1938; GILLIARD, 1946; 
Meyer de Schauensee, 1952; NARosky, 1977; Olson, 1981; STILES, 2004). Adopting this same approach it would be probable that if one male specimen of хитапхи had been collected in the past, it would have been described as a new species, based on the plumage diagnosis (Typological Concept), as occurred with $S$. melanops (Pelzeln, 1870) or even with S. zelichi (NAROsky, 1977; ARETA, 2008).

The absence of spatial segregation (distribution and habitat) between S. melanogaster and xumanxu reinforces the CMH. SicK (1967) and ARETA (2008) argued that habitat segregation is the most important mechanism for isolating breeding populations among Sporophila species. The entire population of $S$. melanogaster occurs in the highest parts of the southern Brazilian highlands (FONTANA et al., 2008) and is sharply segregated, both spatially and with regard to habitat use, from other Sporophila species, especially from the most closely related S. hypoxantha and Sporophila bouvreuil pileata (Sclater, 1864) (REPENNING et al., 2010). It would not make sense if only the rare хитапxи differed from this pattern, and was the only species with a completely syntopic occurrence.

Evaluation of the vocal repertory proved to be an useful tool for testing the taxonomic status of xumanxu such as observed for other closely related species (ARETA 2008; ARETA et al., 2011). The lack of detectable variations in the vocalizations of $S$. melanogaster and the strong similarity to those of xumanxu support the CMH. In contrast to what we know about vocalizations of other congeners, especially non-capuchinos, and even of other oscines, which mimic sounds from allospecific species (Kroodsma, 1996; Thomas, 1996; Sick, 1997), S. melanogaster/xumanxu did not use any note that could be considered an imitation of another bird. This suggests that the species may have some genetic predisposition for learning notes or syllables only from conspecifics.

The temporal differences (over three decades) observed in the vocalizations of $S$. melanogaster and presumably in xumanxu may be attributed to several variables which define the cultural evolution of bird songs (see LyNCH, 1996). However, the fact that the song pattern clearly maintains its homologous note types allows us to deduce that there is a strongly limiting factor in the learning of vocal repertory in this species. This has been previously recognized and described for other species of capuchinos (ARETA, 2008; ARETA et al., 2011). Thus it is even more evident that vocalization is a fundamental feature in species-specific recognition among capuchinos, and must therefore be considered an essential taxonomic character (SICK, 1979). The equivalency in female vocalization between $S$. melanogaster and хитапхи is another evidence in favor of the CMH. The choice of a mate by females very often occurs through vocal repertory, which is an effective mechanism in speciesspecific recognition (RATCLIFFE \& OTTER, 1996). Female call types in different species of capuchinos (e.g., S. hypoxantha and $S$. melanogaster) may be fully diagnosable (pers. obs.), as mentioned by Sick (1967).

The existence of a color morph for S. melanogaster follows the concept of polymorphism or morphs presented by HuXLEY (1955). Accordingly, pairing of breeding couples would not depend on a single male plumage pattern (ARETA et al., 2011). Considering that males of хитапхи were seen reproducing, sexual selection must be a condition for females in some way, which would make the species parameters non-random (GALEOTTI $e t$ al., 2003). It is possible to perceive here a favorable scenario for natural selection processes. The rarity of хитапхи is similar to that observed for the color morphs zelichi and "caraguata", found in Uruguay and centraleastern Argentina (ARETA, 2008; ARETA et al., 2011). Its extreme rarity is a further reason in favor of the $\mathrm{CMH}$ hypothesis.

The discovery of xumanxu further corroborates the color-morph hypothesis for $S$. "zelichi", which was long considered to be a distinct species, and the recently discovered "caraguata" (ARETA, 2008; ARETA et al., 2011). The importance of our findings lies in the discovery of a color morph that does not belong to the "ruficollis group" (sensu ARETA et al., 2011) and other species of capuchinos with distinct cinnamon/chestnut plumage coloration. Several color morphs for capuchinos with defined patterns of male plumage coloration arose independently in different species and populations with allopatric distributions (i.e., zelichi, "caraguata" and now xumanxu), as did other still undescribed forms (e.g., "uruguaya", a color morph for S. hypoxantha [J. I. Areta, pers. comm., and M.R.]. The differentiation of these diagnosable forms seems to derive from the subtle genetic divergences that can act on the male phenotype through changes in plumage color blocks in some individuals (sensu ARETA et al., 2011). There is also the case of the species pairs $S$. cinnamomea/S. hypochroma (Todd, 1915) so far considered to be valid species (ARETA, 2010). This scenario of plumage variations suggests a recent and dynamic radiation, expressed through color morphs and geographical variation in vocalizations (regiolects) (ARETA, 2008; ARETA et al., 2011). Molecular approaches aiming to elucidate the evolutionary history of capuchinos have so far led to convergent conclusions on the group's recent adaptive radiation (LIJTMAER et al., 2004; CAMPAGNa et al., 2009).

The color morph phenomenon, present in several capuchinos, has caused and may continue to cause complex problems in the diagnosis of species of this group, especially in the field. It may become even more confusing if associated with individual variations in pigment saturation (e.g., the mature male phenotype overlapping in S. hypoxantha and S. hypochroma, as mentioned by Fontana et al., 2008:297). Supposing that the same variation pattern described here also occurs in Sporophila castaneiventris (Cabanis, 1849) (see ARETA, 2010), surely the variations would result in forms identical to the phenotype of S. cinnamomea, and would therefore be easily attributed to it if only the plumage is observed. It is, therefore, necessary to continue extensive field studies in order to detect the rarest forms of Sporophila that are not yet described, focusing on collecting basic biological data for each individual, especially their vocalizations. An accurate determination of the identity of the capuchinos is crucial in order to determine the conservation status of each species, so that we can avoid taxonomic confusion and enhance efforts to preserve them. 
Acknowledgments. We are grateful to many colleagues and friends who collaborated in various ways. First, we thank those who kindly provided us with their recordings and/or important literature, including Vítor Q. Piacentini, Dante Buzetti, Bret Withney, L. Campagna, Ismael Franz, and Juan I. Areta. We also thank J.I.A. for helpful discussions on the genus Sporophila and encouragement to write this paper and critical to the manuscript. We also thank Ilsi I. Boldrini for his dedication in identifying the botanical material, which was essential for habitat characterization. Paulo Fenalti and Caco Schwertner contributed a photographic record of xиmanxu from São Francisco de Paula. We are grateful to Janet W. Reid, Giovanni N. Maurício, and Marcos R. Bornschein for valuable suggestions that improved earlier drafts of this paper, and to Glayson Bencke for valuable suggestions on the final version of the manuscript. We acknowledge financial support from Fundação O Boticário de Proteção à Natureza (FBPN-project number 0795-20082), Ministério do Meio Ambiente (MMA), Natural Grassland Conservancy (NGC), and Pontifícia Universidade Católica do Rio Grande do Sul (PUCRS). We dedicate this work to the landowners and friends who allowed us access to their properties, sometimes accommodating us in their homes: Joaquim and Nair Goulart, Antônio and Ivonete Goulart (São Joaquim), Angelo Pegoraro, Sérgio and Petronilia Cardoso, Leonorino and Iracélia Oliboni (Vacaria), Roberto Ivan Penz, and Aldo Pinheiro and Adão Huff (Bom Jesus). To CEMAVE/ICMBio for support, permits, and bird-banding material. To SISBIO for a federal fieldwork permit (number 13310).

\section{REFERENCES}

Areta, J. I. 2008. The Entre Rios Seedeater (Sporophila zelichi): a species that never was. Journal of Field Ornithology 79:352-363.

2009. Pedomorphosis in Sporophila seedeaters. Bulletin of the British Ornithologists' Club 129(2):98-103.

2010. Sistemática y especiación en los Capuchinos (Aves: Sporophila). PhD Dissertation, Universidad Nacional de La Plata, La Plata, Argentina. 182p.

Areta, J. I.; Noriega, J. I.; Pagano, L. \& Roesler, I. 2011. A new Black-collared form of capuchino (Sporophila: Aves), and systematics of the Dark-throated Seedeater (S. ruficollis). Bulletin of the British Ornithologists' Club 131(1):4-23

Beltman, J. B. \& Haccou, P. 2005. Speciation through learning of habitat features. Theoretical Population Biology 67:189-202.

Belton, W. 1985. Birds of Rio Grande do Sul, Brazil. Pt. 2. Formicaridae through Corvidae. Bulletin of the American Museum of Natural History 178(4):369-636.

Bencke, G. A.; Fontana, C. S.; Dias, R. A.; Maurício, G. N. \& Mähler-JR, J. K. F. 2003. Aves. In: Fontana, C. S.; Bencke, G. A. \& ReIs, R. E. eds. Livro vermelho da fauna ameaçada de extinção no Rio Grande do Sul. Porto Alegre, Edipucrs. p.189-479.

Campagna, L.; Lijtmaer, D. A.; Kerr, K. C. R.; Barreira, A. S.; Hebert, P. D. N.; Lougheed, S. C. \& Tubaro, P. L. 2009. DNA Barcodes provide new evidence of a recent radiation in the genus Sporophila (Aves; Passeriformes). Molecular Ecology Resources 10:449-458.

Cody, M. L. 1985. Habitat selection in the sylviine warblers of Western Europe and North Africa In: Cody, M. L. ed. Habitat selection in birds. London, Academic Press. p.4-46.

De Las Casas, J. C. 2004. Evaluación del estado taxonómico del Semillero de Tumaco Sporophila insulata (Fringillidae; Emberizinae) utilizando métodos morfológicos y genéticos. Tesis de Pregrado. Universidade Nacional de Colombia, Bogotá, Colombia. 47p.

Facchinetti, C.; Di Giacomo, A. \& Reboreda, J. C. 2008. Parental care in Tawny-bellied (Sporophila hypoxantha) and Rustycollared ( $S$. collaris) Seedeaters. The Wilson Journal of Ornithology 120(4):879-883.

Fontana, C. S.; Rovedder, C. E.; Repenning, M. \& Gonçalves, M. L. 2008. Estado atual do conhecimento e conservação da avifauna dos Campos de Cima da Serra do sul do Brasil, Rio Grande do Sul e Santa Catarina. Revista Brasileira de Ornitologia 16(4):281-307.

Galeotti, P.; Rubolini, D.; Dunn, P. O. \& Fasola, M. 2003. Colour polymorphism in birds: causes and functions. Journal of Evolutionary Biology 16:635-646.

Gilliard, E. T. 1946. Two new Gray Seed-eaters from South America. Auk 63:570-574.

HAFFER, J. 1997. Species concepts and species limits in ornithology. In: Del Hoyo, J.; Elliott, A. \& Sargatal, J. eds. Handbook of the Birds of the World, 4. Sandgrouse to cuckoos. Barcelona, Lynx Editions. p.11-24.

Hellmayr, K. E. 1938. Catalogue of Birds of the Americas and adjacent islands. Field Museum of Natural History, Zoological Series, Vol. 13, Pt. XI. Chicago. 662p.

Huxley, J. 1955. Morphism in birds. Acta International Congress Ornithology XI. p.309-328.

Kroodsma, D. E. 1996. Ecology of Passerine song development. In: Kroodsma, D. E. \& Miller, E. H. eds. Ecology and evolution of acoustic communication in birds. Ithaca, Cornell University. p.3-19.

Litmaer, D.; Sharpe, N. M. M.; Tubaro, P. L. \& Lougheed, S. C. 2004. Molecular phylogenetics and diversification of the genus Sporophila (Aves: Passeriformes). Molecular Phylogenetics and Evolution 33:562-579.

Lima, E. M. C. 2008. Taxonomia, distribuição e conservação dos "caboclinhos" do complexo Sporophila bouvreuil (Aves: Emberizidae). Dissertação de Mestrado. Instituto de Biociências da Universidade de São Paulo. Departamento de Zoologia. 246p.

Lynch, A. 1996. The population memetics of birdsong. In: Kroodsma, D. E. \& Miller, E. H. eds. Ecology and evolution of acoustic communication in birds. Ithaca, Cornell University. p.181-195.

Meyer de Schauensee, R. 1952. A review of the genus Sporophila. Proceedings of the Academy of Natural Sciences of Philadelphia 54:153-198.

Narosky, S. 1977. Una nueva especie del género Sporophila. Hornero 11:345-348.

OLSON, S. L. 1981. The nature of the variability in the Variable Seedeater in Panama (Sporophila americana: Emberizinae). Proceedings of the Biological Society of Washington 94:380-390.

Ouellet, H. 1992. Speciation, zoogeography and taxonomic problems in the Neotropical genus Sporophila (Aves: Emberizinae). Bulletin of the British Ornithologists' Club (Centenary Supplement) 112a:225-235.

Paterson, H. E. H. 1985. The recognition concept of species. In: VRba, E. S. ed. Species and speciation. Transvaal Museum Monographs 4:21-29.

Ratcliffe, L. \& OtTER, K. 1996. Sex differences in song recognition. In: Kroodsma, D. E. \& Miller, E. H. eds. Ecology and evolution of acoustic communication in birds. Ithaca, Cornell University. p.339-353.

Repenning, M.; RovedDer, C. E. \& Fontana, C. S. 2010. Distribuição e biologia de aves nos campos de altitude do sul do Planalto Meridional Brasileiro. Revista Brasileira de Ornitologia 18(4):283-306.

Ridgely, R. S. \& Tudor, G. 1989. The birds of South America. Vol 1. Austin, University of Texas. 521p.

Schwartz, P. 1975. Solved and unsolved problems in the Sporophila lineola/bouvronides complex (Aves: Emberizidae). Annals of the Carnegie Museum, Pittsburgh 45:277-285.

SноRт, L. L. 1969. Relationships among some South American seedeaters (Sporophila), with a record of S. hypochroma for Argentina. The Wilson Bulletin 81:216-219.

Sick, H. 1963. Hybridization in certain Brazilian Fringillidae (Sporophila and Oryzoborus). Proceedings of the XIII International Ornithological Congress. p.161-170. . 1967. "Bico de Ferro" - Overlooked seedeater from Rio de Janeiro (Sporophila, Fringillidae, Aves). Anais Academia Brasileira de Ciências 39:307-314. 
1979. A voz como caracter taxonômico em aves. Boletim do Museu Nacional, Nova Série, Zoologia, 294:1-11.

1997. Ornitologia brasileira. Rio de Janeiro, Nova Fronteira. $862 \mathrm{p}$.

StiLEs, G. 1996. When black plus white equals gray: The nature of variation in the Variable Seedeater complex (Emberizinae: Sporophila). Ornitología Neotropical 7:75-107.

. 2004. The Tumaco Seedeater (Sporophila insulata,
Emberizidae): a species that never was? Ornitología Neotropical 15:17-30.

THOMAs, B. T. 1996. Notes on the distribution, body mass, foods and vocal mimicry of the Gray Seedeater (Sporophila intermedia). Ornitología Neotropical 7:165-169.

TodD, W. E. C. 1915. Preliminary diagnoses of apparently new South American birds. Proceedings of the Biological Society of Washington 28:79-82.

Recebido em outubro de 2010. Aceito em dezembro de 2010. ISSN 0073-4721

Artigo disponível em: www.scielo.br/isz

Impresso e distribuído em 2011. 